\title{
sciendo
}

\section{THE IMPACT OF TREATED WASTEWATERS ON FISH BACTERIAL FLORA: A PUBLIC HEALTH PERSPECTIVE}

\author{
Natalija Topić Popović ${ }^{1}$, Slavko Kepec ${ }^{2,3}$, Snježana P. Kazazićc ${ }^{4}$, Josip Barišić ${ }^{1}$, Ivančica Strunjak-Perović ${ }^{1 *}$, \\ Sanja Babić ${ }^{1}$, Rozelindra Čož-Rakovac ${ }^{1}$
}

\author{
${ }^{1}$ Laboratory for Aquaculture Biotechnology, Rudjer Bošković Institute, Zagreb, Croatia \\ ${ }^{2}$ Virkom d.o.o., Public Water Supply and Wastewater Services, Virovitica, Croatia \\ ${ }^{3}$ Faculty of Medicine, Josip Juraj Strossmayer University of Osijek, Croatia \\ ${ }^{4}$ Laboratory for Mass Spectrometry, Rudjer Bošković Institute, Zagreb, Croatia
}

*Corresponding Author, Email: strunjak@irb.hr

\section{ARTICLE INFO}

Received: 4 March 2019

Accepted: 24 June 2019

\begin{abstract}
Wastewaters from a treatment plant discharging into a canal harboring fish may present sources of microbiological hazard for wild fish. Such fish, inhabiting microbiologically polluted bodies of water, can be contaminated by human pathogens and, if used for human consumption, may pose a risk to public health. Hence, in this work the aim was to identify tested strains from tissues of wild fish living in the receiving water bodies, captured from locations up to $12 \mathrm{~km}$ from the point of discharge of treated water of town Virovitica in order to assess the bacterial threat of the WWTP on fish and potentially on public health. A rather rich diversity of bacterial genera was isolated from gill tissues and internal organs. The most frequent isolate was Aeromonas hydrophila which has gained public health recognition as an opportunistic pathogen. Vibrio cholerae, an indicator bacterium for aquatic contamination, was retrieved from all investigated tissues. Opportunistic human pathogens as well as some zoonotic agents were also retrieved from fish tissues (Enterobacter amnigenus, Acinetobacter spp., Ochrobactrum anthropi, Pseudomonas aeruginosa, Flavimonas (Pseudomonas) oryzihabitans, Shewanella putrefaciens and others). Public health hazard is particularly pronounced regarding local recreational fishermen who fish out, handle and consume fish from respective waters.

Topić Popović, N., Kepec, S., Kazazić, S.P., Barišić, J., Strunjak-Perović, I., Babić, S., Čož-Rakovac, R. (2019): The impact of treated wastewaters on fish bacterial flora: a public health perspective. Croatian Journal of Fisheries, 77, 132-135. DOI: 10.2478/cjf-2019-0015.
\end{abstract}




\section{INTRODUCTION}

The effluents from wastewater treatment plants (WWTPs) discharging into rivers and streams have been recognized as potential sources of deterioration of fish health. Their overall impacts have mostly been assessed by holding fish in cages fixed onto the river bottom. Less is known of the impacts of treated wastewaters on wild fish living in receiving water bodies, including further downstream locations.

Microbial sewage communities consist of a combination of human fecal microorganisms and nonfecal microorganisms, which may be residents of WWTPs or originate from gray waters or rainwater inputs (Shanks et al., 2013). Such complex microbial community found in treated WWTP effluents, although significantly reduced (particularly in fecal indicator bacteria), might still contain pathogenic bacteria which present a threat to fish living downstream (Topić Popović et al., 2015). On the other hand, fish inhabiting microbiologically polluted bodies of water can be contaminated by human pathogens and, if used for human consumption, may pose a risk to public health (Fattal et al., 1992).

Microbiological examination and monitoring is commonly used worldwide to ensure the safety of a range of water sources whereby contamination with excreta could pose health risks. The public health risk presents the main concern in the more frequent use of treated wastewaters for fish farming and crop irrigation (El-Shafai et al, 2004; Piveli et al, 2008). Although many potential pathogens could be associated with contaminated water, representative indicators are used as means to detect microbial pollution (Naidoo and Olaniran, 2014). Hence, in this work the aim was to identify tested strains from tissues of wild fish living in the receiving water bodies, captured from locations approximately 10 and $12 \mathrm{~km}$ from the point of discharge of treated water in order to assess the bacterial threat of the WWTP on fish and potentially public health.

\section{MATERIAL AND METHODS}

The samplings were conducted throughout a yearly treatment process of a Croatian municipal WWTP in Virovitica. The WWTP treatment includes primary and secondary processes, and the final treated effluent is discharged into a natural water canal. Further downstream, this canal receives additional communal treated water from a biological treatment plant serving a small suburb, it widens to enter a county canal, which eventually ends up in the Drava River. Fish were captured by nets and angling in the canal before inflowing into the Drava some 10 and $12 \mathrm{~km}$ from the WWTP discharge. Specimens were randomly sampled, transported live to the laboratory and sacrificed by overdose of tricaine methane-sulfonate (MS222, Sigma, St. Louis, Missouri, USA) within few hours after capture. Although several species were captured (Carassius gibelio, Ictalurus nebulosus, Squalius cephalus, Abramis brama, Rutilus rutilus, Alburnus alburnus and Tinca tinca), the majority of specimens were Prussian carp (Carassius gibelio), thus for uniformity in this work only they are considered. A total of 60 carp of both sexes were subjected to examination (mean weight $145.53 \pm 65.18 \mathrm{~g}$, mean length $171.6 \pm 31.98 \mathrm{~mm}$ ).

Samples of fish gills, kidney and liver were streaked onto Tryptone Soya Agar, MacConkey Agar (Oxoid) and Blood Agar (Certifikat doo, Croatia). Representative colonies were isolated and restreaked on fresh medium until purity was attained. Pure colonies were Gram-stained and subjected to morphological, physiological and biochemical tests.

Total viable counts and methods for detection and enumeration of bacteria were: Enumeration of culturable microorganisms - Colony count by inoculation in a nutrient agar culture medium (ISO 6222:1999); Methods for detection and enumeration of Escherichia coli, coliforms and enterococci according to the Detection and enumeration of $E$. coli and coliform bacteria - Part 1: Membrane filtration method (ISO 9308-1:2000/ Corr.1:2008) and Detection and enumeration of intestinal enterococci - Part 2: Membrane filtration method (ISO 7899-2:2000). E. coli, coliforms and enterococci were measured from skin and gill scrapings; General guidance for enumeration of yeasts and moulds - Colony count technique at 25 degrees C (ISO 21527-1:2008, ISO 215272:2008).

The taxonomic position of the isolates was determined by API 20E panels (bioMerieux, Marcy l'Etoile, France) and Bruker Biotyper MALDI TOF MS. The API 20E tests were performed according to the manufacturer's instructions with a few alterations in order to adapt the system to the bacteria of freshwater fish as described in Topić Popović et al. (2007).

\section{RESULTS AND DISCUSSION}

Bacterial colony counts at $22^{\circ} \mathrm{C}$ from gills and skin of investigated fish ranged from $1.38 \times 10^{6}$ to $1.8 \times 10^{6} \mathrm{CFU}$ $\mathrm{mL}^{-1}$, and $1.03 \times 10^{6}$ to $5.3 \times 10^{6} \mathrm{CFU} 100 \mathrm{~mL}^{-1}$, respectively. Bacterial colony counts at $37^{\circ} \mathrm{C}$ from gills and skin ranged from $3 \times 10^{2}$ to $5.9 \times 10^{5} \mathrm{CFU} \mathrm{mL}^{-1}$, and from $3.02 \times 10^{2}$ to 5.3 $x 10^{6} \mathrm{CFU} 100 \mathrm{~mL}^{-1}$, respectively. Maximum concentrations of yeasts and molds were lower in fish skin than in gills (yeasts $6 \mathrm{CFU} \mathrm{mL} \mathrm{m}^{-1}$ and $380 \mathrm{CFU} \mathrm{mL}^{-1}$, respectively; molds

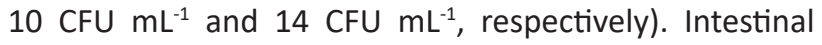
enterococci concentrations amounted to $25 \mathrm{CFU} 100 \mathrm{~mL}^{-1}$. From gills, fecal coliforms and E.coli were not isolated. From skin, fecal coliforms, E.coli, P. aeruginosa and sulphitereducing clostridia were not isolated, nor from any of the internal organs. Although fecal indicator bacteria were not retrieved in large numbers in downstream fish, and fecal coliforms and intestinal enterococci in this study were 
not significantly elevated in water bodies from which fish were captured (Topić Popović et al., 2015a), there is a risk of pathogens penetrating fish tissues. It rises if the total counts of heterotrophic aerobic bacteria exceed $10^{4} \mathrm{CFU}$ $\mathrm{mL}^{-1}$ of such water, and usually only fecal contamination indicators are used for such estimations (Molleda et al., 2008; Harnisz and Tucholski, 2010). Bacterial genera isolated from fish tissues are presented in Figure 1.

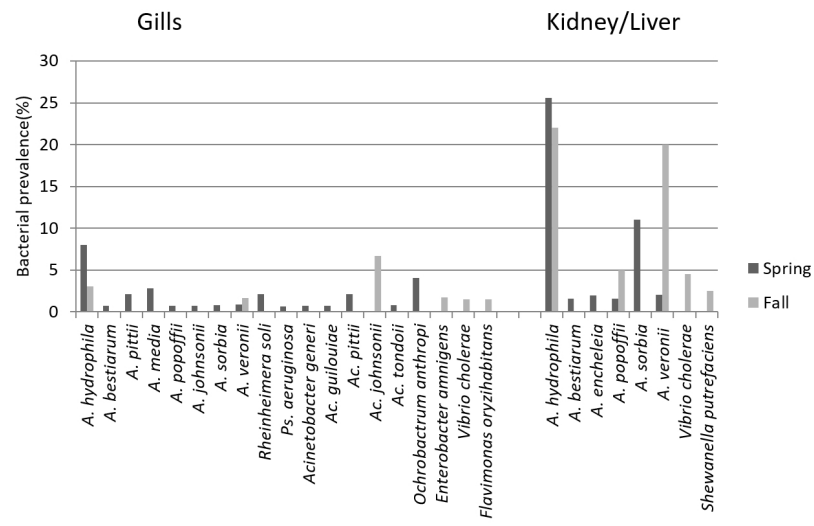

Fig 1. Distribution of bacterial genera isolated from fish gills and internal organs over the representative seasons

A rather rich diversity of species was noted, more prominently in gill tissues. The most frequent isolate, by both identification methods applied, was Aeromonas hydrophila which has gained public health recognition as an opportunistic pathogen (Cabral, 2010). Also, Vibrio cholerae was retrieved from all tissues, an important species listed as an indicator bacterium for aquatic contamination (Cabral, 2010). Enterobacter amnigenus was also isolated from gill tissues. Although it was previously described as a human pathogen impacting only immunocompromised patients (Capdevilla et al., 1998), it was proven to cause infections in immunocompetent individuals as well (Westerfeld et al., 2009). The retrieved genus Acinetobacter is a major cause of nosocomial infections, increasingly being associated with various epidemics and has become a widespread concern in a variety of hospitals worldwide (Almasaudi, 2016). Isolated Ochrobactrum anthropi, an aerobic, gram-negative bacillus widely distributed in environmental sources, appears to be an emerging opportunistic human pathogen as well (Hernandez-Torres et al., 2014). Pseudomonas aeruginosa, both fish and a human pathogen, was a rather rare finding in this work, as well as Flavimonas (Pseudomonas) oryzihabitans, human opportunistic pathogen (Qian and Wang, 2001). Reports of human infections with Shewanella (Pseudomonas) putrefaciens, isolated from fish internal organs in this work and frequently isolated from sewage, are also on the rise (Sharma and Kalawat, 2010). Having in mind the pathogenicity and zoonotic potential of strains isolated from wild fish, particularly of the omnipresent $A$. hydrophila (causing tail/fin rot, lesions, ulcers, abscesses, exophthalmia, abdominal distension and haemorrhagic septicaemias in fish), the transfer to humans will probably reflect the handling of diseased specimens (Austin and Austin, 2007). Therefore, there is a health concern regarding pathogen exposure to humans, particularly with recreational fishermen who fish in the investigated canal, and also with crew operating the WWTP, being exposed to aerosols of wastewaters. A. hydrophila in particular may cause fish handler disease through skin wound infections and systemic infections, while, as food-borne, it may lead to gastroenteritis, diarrhea, meningitis and systemic infections (Goni-Urriza et al., 2000; Lehane and Rawlin, 2000; Huddleston et al., 2006; Austin and Austin, 2007; Cabral, 2010; Cabello et al., 2013). Therefore, occupational and recreational exposure to treated wastewater pathogens spread into fish tissues may affect particularly immunocompromised or chronically affected patients (Cabral, 2010). Uptake into humans thus may be via cuts or grazes, or via the digestive tract (Austin and Austin, 2007). Because of their capacity to cross distances, fish are in position to carry potential human pathogens to non-polluted waters, causing infections when they are handled or consumed (Guzman et al., 2004). For that reasons, detection of indicator and pathogen organisms, not only in treated wastewaters but also in fish inhabiting them, should be targeted in national guidelines and regulations related to management controls and sanitary surveys.

\section{SAŽETAK}

\section{UTJECAJ PROČIŠĆENIH OTPADNIH VODA NA BAKTERIJSKU FLORU RIBA S PERSPEKTIVE JAV- NOG ZDRAVSTVA}

Pročišćene otpadnevode, koje se izlijevaju u kanal u kojemu obitavaju slobodnoživuće ribe, po njih predstavljaju izvore mikrobiološke opasnosti. Riblje vrste koje nastanjuju mikrobiološki onečišćene vode mogu biti kontaminirane i humanim patogenima te predstavljati opasnost po javno zdravstvo ukoliko ih se koristi za konzumaciju. Stoga je u ovom radu cilj bio identificirati izolirane bakterijske sojeve iz tkiva slobodnoživućih riba prihvatnih voda, izlovljenih do oko $12 \mathrm{~km}$ nizvodno od izljeva pročišćenih voda grada Virovitice, kako bi se procijenio mikrobiološki rizik po zdravlje riba i ljudi koji sa njima dolaze u doticaj. Identificirano je više vrsta i rodova bakterija izoliranih iz škrga, bubrega i jetara babuške. Najzastupljeniji izolat bio je Aeromonas hydrophila, oportunistički patogen velikog značenja za javno zdravstvo. Iz svih tkiva riba izoliran je i Vibrio cholerae, indikator akvatičke kontaminacije, a osim njih još nekoliko zoonotičkih i oportunističkih humanih patogena (Enterobacter amnigenus, Acinetobacter spp., Ochrobactrum anthropi, Pseudomonas aeruginosa, Flavimonas (Pseudomonas) oryzihabitans, Shewanella putrefaciens i dr.). Opasnost po javno zdravstvo posebice 
je izražena kod lokalnih ribiča koji u pročišćenim vodama ribu love, njome manipuliraju i pripremaju je za konzumaciju.

Ključne riječi: bakterije, babuška, otpadne vode

\section{REFERENCES}

Almasaudi, S.B. (2016): Acinetobacter spp. as nosocomial pathogens: Epidemiology and resistance features. Saudi Journal of Biological Sciences, 25, 3, 586 - 596.

Austin, B., Austin, D. (2007): Bacterial fish pathogens: Disease in farmed and wild fish. Laird L. (ed) $4^{\text {th }}$ ed, Springer-Praxis series in aquaculture and fisheries. Praxis Publishing Ltd, Chichester UK.

Cabello, F.C., Godfrey, H.P., Tomova, A., Ivanova, L., Dolz, H., Millanao, A., Buschmann, A.H. (2013): Antimicrobial use in aquaculture re-examined: its relevance to antimicrobial resistance and to animal and human health. Environmental Microbiology, 15, 7, 1917-1942.

Cabral, J.P.S. (2010): Water microbiology. Bacterial pathogens and water. International Journal of Environmental Research and Public Health, 7, 36573703.

Capdevilla, J.A., Bisbe, V., Gasser, I. Zuazu, J. Olive, T., Fernandez, F., Pahissa Berga, A. (1998): Enterobacter amnigenus. An unusual human pathogen. Enfermedades Infecciosas Y Microbiologia Clinica, 16, 8, 364-366. (Article in Spanish, Abstract in English)

El-Shafai, S.A., Gijzen, H.J., Nasr, F.A., El-Gohary, F.A. (2004): Microbial quality of tilapia reared in fecalcontaminated ponds. Environmental Research, 95, 231-238.

Fattal, B., Dotan, A., Tchorsh, Y. (1992): Rates of experimental microbiological contamination of fish exposed to polluted water. Water Research, 26, 12, 1621-1627.

Goni-Urriza, M., Pineau, L., Capdepuy, M., Roques, C., Caumette, P., Quentin, C. (2000): Antimicrobial resistance of mesophilic Aeromonas spp. strains isolated from two European rivers. Journal of Antimicrobial Chemotherapy, 46, 297-301.

Guzman, M.C., Bistoni, M.A., Tamagnini, L.M., Gonzalez, R.D. (2004): Recovery of Escherichia coli in fresh water fish, Jenynsia multidentata and Bryconamericus iheringi, Water Research, 38, 2368-2374.

Harnisz, M., Tucholski, S. (2010): Microbial quality of common carp and pikeperch fingerlings cultured in a pond fed with treated wastewater. Ecological Engineering, 36, 466-470.

Hernandez-Torres, A., Ruiz Gomez, J., Garcia-Vazquez, E., Gomez-Gomez, J. (2014): Ochrobactrum Anthropi Bacteraemia: Report of Six Cases and Review of the Literature. Internal Medicine: Open Access, doi: http:// dx.doi.org/10.4172/2165-8048.1000134
Huddleston, J.R., Zak, J.C., Jeter, R.M. (2006): Antimicrobial susceptibilities of Aeromonas spp. isolated from environmental sources. Applied and Environmental Microbiology, 72, 11, 7036-7042.

Lehane, L., Rawlin, G.T. (2000): Topically acquired bacterial zoonoses from fish: a review. Medical Journal of Australia, 173, 5, 256-259.

Molleda, P., Blanco, I., Ansola, G., de Luis, E. (2008): Removal of wastewater pathogen indicators in a constructed wetland in Leon, Spain. Ecological Engineering, 33, 252-257.

Naidoo, S., Olaniran A.O. (2014): Treated wastewater effluent as a source of microbial pollution of surface water resources. International Journal of Environmental Research and Public Health, 11, 249-270.

Piveli, R.P., Gunther, W.M., Matté, G.R., Razzolini, M.T., Cutolo, S.A., Martone-Rocha, S., Peternella, F.A., Dória, M.C., Matté, M.H. (2008): Sanitation assessment of wastewater treated by stabilization ponds for potential reuse in agricultural irrigation sanitation assessment. Water Environmental Research, 80, 3, 205-211.

Qian, K., Wang, S. (2001): Infections caused by Flavimonas oryzihabitans. Chinese Medical Journal, 114, 4, 394398.

Shanks, O.C., Newton, R.J., Lelty, C.A., Huse, S.M., Sogin, M.L., McLellan S.L. (2013): Comparison of the microbial community structures of untreated wastewaters from different geographic locales. Applied and Environmental Microbiology, 79, 9, 2906-2913.

Sharma, K.K., Kalawat, U. (2010): Emerging Infections: Shewanella - A Series of Five Cases. Journal of Laboratory Physicians, 2, 2, 61-65.

Topić Popović, N., Čož-Rakovac, R., Strunjak-Perović, I. (2007): Commercial phenotypic tests (API 20E) in diagnosis of fish bacteria. Veterinarni Medicina, 52, 2, 49-53.

Topić Popović, N., Kazazić, S., Strunjak-Perović, I., Barišić, J., Sauerborn Klobučar, R., Kepec, S., Čož-Rakovac, R. (2015): Detection and diversity of aeromonads from treated wastewater and fish inhabiting effluent and downstream waters. Ecotoxicology and Environmental Safety, 120, 235-242.

Topić Popović, N., Strunjak-Perović, I., Sauerborn Klobučar, R., Barišić, J., Babić, S., Jadan, M., Kazazić, S., Matijatko, V., Beer Ljubić, B., Car, I., Repec, S., Stipaničev, D., Klobučar, G., Čož-Rakovac, R. (2015a): Impact of treated wastewater on organismic biosensors at various levels of biological organization. Science of the Total Environment, 538, 23-37.

Westerfeld, C., Papaliodis, G., Behlau, I., Durand, M., Sobrin, L. (2009): Enterobacter amnigenus endophthalmitis. Retinal Cases and Brief Reports, 3, 4, 409-411. 